\title{
Macroinvertebrates in low-order streams in two fragments of Atlantic Forest in different states of conservation, in the State of São Paulo (Brazil)
}

\author{
Paula, MC. ${ }^{\mathrm{a} *}$ and Fonseca-Gessner, $A \mathrm{~A}^{\mathrm{b}}$ \\ aPrograma de Pós-graduação em Ecologia e Recursos Naturais, Universidade Federal de São Carlos - UFSCar, \\ Rod. Washington Luiz, Km 235, CP 676, CEP 13565-905, São Carlos, SP, Brazil \\ ${ }^{\text {b}}$ Laboratório de Entomologia Aquática, Departamento de Hidrobiologia, Universidade Federal de São Carlos - UFSCar, \\ CP 676, CEP 13565-905, São Carlos, SP, Brazil \\ *e-mail: marciacdp@ig.com.br \\ Received November 30, 2009 - Accepted February 24, 2010 - Distributed October 31, 2010
}

(With 3 figures)

\begin{abstract}
The presence of a riparian forest is one of the main factors that act directly on the ecology of a fluvial system, and the relation of the forest and the lotic environments might have an important influence on the distribution of the macroinvertebrates. In this context, the benthic macroinvertebrate communities in four low-order streams in São Paulo (Brazil) were analysed, with the aim of assessing the state of recovery of the surrounding forest fragments. The benthic organisms were sampled in the winter, a period of low rainfall. Of the 6,331 specimens of macroinvertebrates collected, 124 taxa belonging to 48 families were identified. The results showed greater diversity in the Canchim Farm streams and greater abundance in the Lake Park streams. Cluster analysis showed that the stream Canchim distanced itself from the others, being considered reference.
\end{abstract}

Keywords: conservation, recovery of riparian forest, environmental monitoring, low-order streams.

\section{Macroinvertebrados em córregos de baixa ordem em dois fragmentos de Mata Atlântica em diferentes estados de conservação, no Estado de São Paulo (Brasil)}

\begin{abstract}
Resumo
A presença da mata ripária é um dos principais fatores que atuam diretamente na ecologia de um sistema fluvial, e a relação da mata e o ambiente lótico pode ter influência importante na distribuição dos macroinvertebrados. Neste contexto, as comunidades de macroinvertebrados bentônicos de quatro córregos de baixa ordem situados no interior do Estado de São Paulo foram estudadas, visando avaliar as condições de recuperação de um fragmento de mata. Os macroinvertebrados foram amostrados no período de inverno com baixa precipitação de chuva. Dos 6.331 espécimes de macroinvertebrados coletados, foram identificados 124 táxons distribuídos em 48 famílias. Os resultados indicaram maior diversidade nos córregos da fazenda Canchim e maior abundância nos córregos do Parque do Lago. A análise de agrupamento mostrou que o córrego Canchim se distanciou dos demais, sendo considerado referência.
\end{abstract}

Palavras-chave: conservação, recuperação de mata ciliar, monitoramento ambiental, córregos de baixa ordem.

\section{Introduction}

Headwater streams are important areas for biodiversity and have gained much attention in various countries in different geographic regions. However, according to Clarke et al. (2008), the word 'important' is ambiguous in this context and it is uncertain whether headwater streams should be described as such, because they contain species that are restricted to these systems, or because they have high taxonomic richness, or because they may have undescribed species.

The existence or otherwise of gallery forest beside river systems is one of the main factors influencing their ecological health (Dudgeon, 1988) and the relation of the forest to the freshwater habitat has a strong effect on the distribution of aquatic insects (Vannote et al., 1980). It should be emphasised that preservation of this riparian zone beside the river is crucial to the maintenance of its morphology, as it holds back the erosion of the banks. Moreover, it increases the flow of allochthonous plant material, such as leaves, wood and fruits, that adds to the heterogeneity of the habitat (Kikuchi and Uieda, 1998) and hence increases the variety of food items and available niches (Hynes, 1970). 
Streams are characterised by the form of the land and their biota, which is influenced by the quality and complexity of the habitat (Allan, 2004). Thus, changes in the riverside plant cover, involving replacement or removal of forest on a large or small scale, have direct or indirect effects on the condition of the stream and hence on the biota.

The "ecological integrity" and "condition" of streams and rivers are terms used to describe the state of conservation of these ecosystems, particularly with respect to their response to changes arising from human interference (Allan, 2004). The condition of the water body can be assessed by the overall similarity between the test site and chosen reference sites, measured by comparing various physicochemical or biological indicator variables, or a combination of both.

In southeast Brazil, the impact of the replacement of native forest by coffee, sweetcorn or cotton plantations, later by cattle pasture and nowadays by enormous stretches of sugarcane monoculture, is responsible for the widespread and continuing degradation of native forest, which is becoming more and more fragmented and even, not infrequently, involves the removal of riverside forest (Rodrigues and Leitão Filho, 2001).

Considering the importance of lotic ecosystems, especially low-order streams, the current degradation of the remaining fragments of riparian forest in the state of São Paulo, and based on the assumption that the macroinvertebrate community reflects the state of preservation of the environment, this study was carried out to assess the condition of the fauna in four streams that run through two forest fragments (remaining from the original Atlantic Forest) in different states of conservation.

\section{Materials and Methods}

\subsection{Study area}

Four low-order streams (see Figure 1) within two remnants of Atlantic Forest in São Paulo were chosen for this study: (1) the Canchim and Sistema streams in the forested area of Canchim Farm, a permanently-protected area that is a 100 ha fragment of Atlantic Forest belonging to the Southeast Brazil Animal-husbandry Research Center

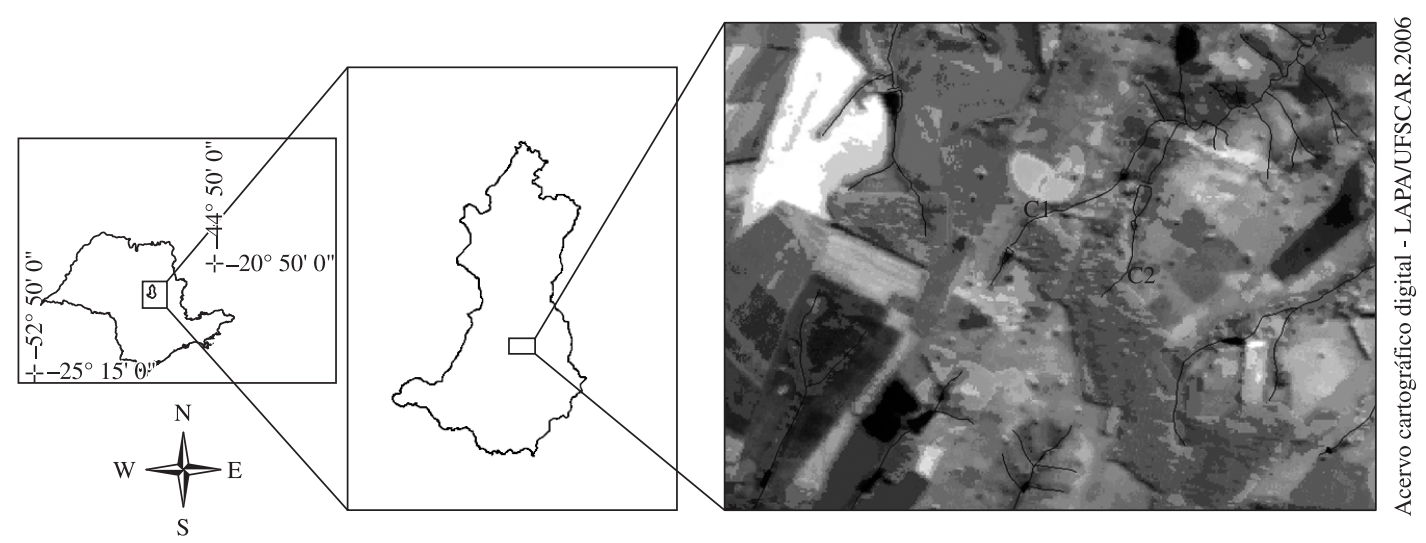

Projeção UTM - 23S

South American Datum

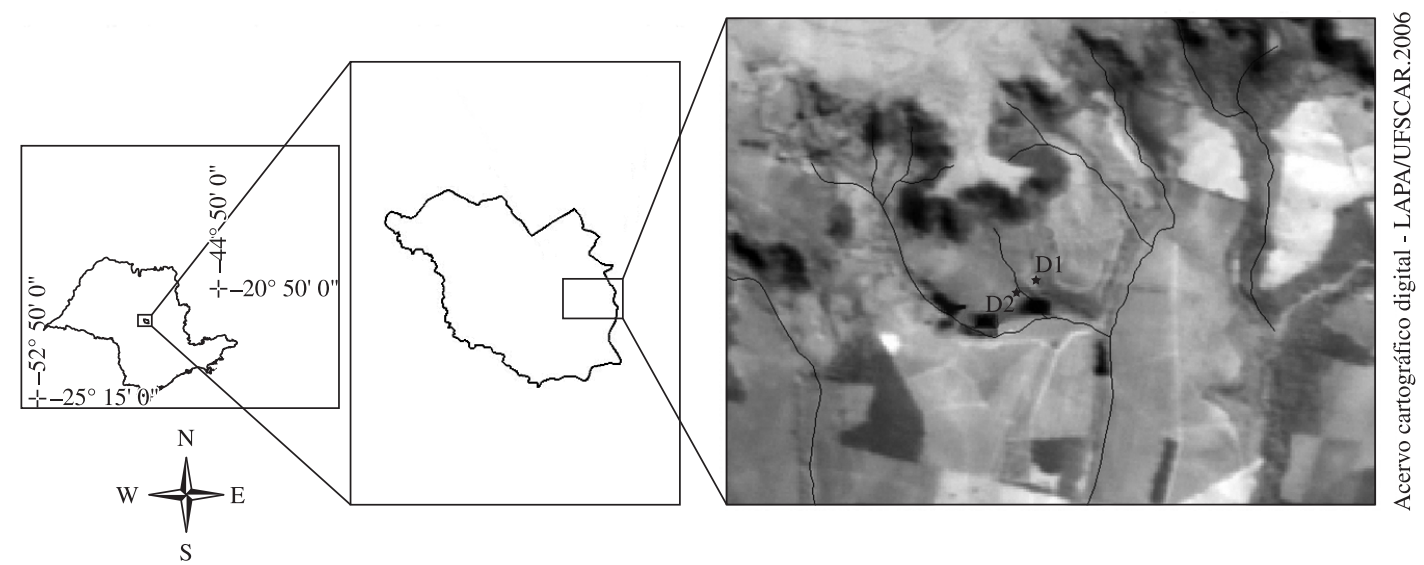

LAT/LONG

South American Datum 1969

Figure 1. Location of the Camchim (C2) and Sistema (C1); Mina da Casinha (D2) and das Furnas (D1) streams. 
run by EMBRAPA (the Federal agency for the advancement of agriculture) in the São Carlos district; (2) the Mina da Casinha and das Furnas streams in Parque do Lago (Lake Park), a private area in Dourado, where the riparian forest of these streams is in process of recovery - in recent years, 21,000 native trees have been planted and the existing riparian forest covers 1.02 ha, while the reforested area covers an additional 1.78 ha.

\subsection{Sampling and data analysis}

Physiognomic features of the streams, such as the amount of canopy cover and width of riparian zone, were recorded at each sampling site, as well as the depth of the water column and breadth of the channel. In addition, the mean speed of the current was calculated by the float method (Lind, 1979) and the physicochemical properties of the water used (temperature; electrical conductivity; dissolved oxygen; oxygen saturation; hydrogen ion potential; dissolved solids) to assess quality were measured with a YSI 556 MPS (multiprobe system).

Macroinvertebrates were collected in the dry season (August 2006) in three $20 \mathrm{~m}$ stretches in a $100 \mathrm{~m}$ section of each stream. Six samples were taken at each site with a Surber sampler $(30 \times 30 \mathrm{~cm}$, mesh $250 \mu \mathrm{m})$; in addition, 3 sweeps of $1 \mathrm{~m} 30$ s were carried out in each stream, one in each $20 \mathrm{~m}$ stretch, with a D-shaped hand net. The organisms were identified to the lowest possible taxonomic level, with the aid of identification keys and specialised articles: Ephemeroptera (Domínguez et al., 2001; Salles et al., 2004; Domínguez et al., 2006), Plecoptera (Froehlich, 1998; Fernández and Domíngues, 2001; Olifiers et al., 2004), Trichoptera (Wiggins, 1996; Angrisano and Korob, 2001; Pes et al., 2005), Chironomidae (Trivinho-Strixino and Strixino, 1995), Odonata (Costa, JM. et al., 2003), Coleoptera (Bertrand, 1972; Leech and Chandler, 1956; Costa, C. et al., 1988; White and Brigham, 1996; Epler, 1996; Manzo, 2005), Megaloptera (Fernández and Domíngues, 2001), Oligochaeta (Brinkhurst and Marchese, 1989).
The macroinvertebrate communities of each stream were compared in terms of the following metrics: abundances; taxon richness: observed $(\mathrm{S})$ and estimated for 350 organisms $\left(\mathrm{S}^{*}\right)$ from the rarefaction curve; Shannon diversity index $\left(\mathrm{H}^{\prime}\right)$ based on $\ln (\mathrm{x}+1)$ - transformed data; Simpson diversity index (1-D), where D is Simpson's dominance; Margalef richness index (d); Pielou's evenness (E); \% EPT, \% Chironomids and EPT/Chironomids ratio and to verify the similarity between the streams, the Bray-Curtis dissimilarity index with data transformed to $\log _{10}(\mathrm{x}+1)$ and connection method type UPGMA was used.

\section{Results}

The streams under study, in both of the forest remnants, were found to be shallow and narrow, with well-oxygenated water, mean temperature around $20^{\circ} \mathrm{C}$, low electrical conductivity, near-neutral $\mathrm{pH}$ and low dissolved solid contents (see Table 1). In the Canchim Farm, the Canchim stream is in the middle of the conserved forest area and thus covered by a closed canopy, while the Sistema runs along the edge of the forest, so that one of its banks is exposed to an area of cattle grazing and the canopy cover is more open. In Lake Park, the recovering riparian forest alongside the Mina da Casinha and das Furnas streams is narrow (less than $30 \mathrm{~m}$ wide) and the canopy cover is thinner, increasing the incidence of light on the streams and enabling higher autochthonous production.

The 6,331 macroinvertebrate specimens were found to belong to 124 taxa in 48 families. The streams in the older Canchim forest were populated by a larger number of species: 104 taxa were identified in 40 families, in a total of 1,575 specimens, of which 1,217 were found in the Canchim stream, where Leptohyphodes and Dryops predominated, and 358 in the Sistema stream, where Dryops was the most common genus. The streams in Lake Park reached overall abundances three times greater than those in the Canchim Farm, but the taxon richness was lower. The

Table 1. Geographic location and mean observed environmental variables of the Canchim, Sistema, Mina da Casinha (Mina) and das Furnas (Furnas) streams.

\begin{tabular}{|c|c|c|c|c|}
\hline & Canchim & Sistema & Mina & Furnas \\
\hline Location & $\begin{array}{c}21^{\circ} 57^{\prime} 42^{\prime \prime} \mathrm{S} \text { and } \\
47^{\circ} 50,28 " \mathrm{~W}\end{array}$ & $\begin{array}{c}21^{\circ} 57^{\prime} 31^{\prime} " \mathrm{~S} \text { and } \\
47^{\circ} 50^{\prime} 58 " \mathrm{~W}\end{array}$ & $\begin{array}{c}22^{\circ} 07 ' 44 " \mathrm{~S} \text { and } \\
48^{\circ} 16^{\prime} 10^{\prime} " \mathrm{~W}\end{array}$ & $\begin{array}{c}22^{\circ} 07^{\prime} 41^{\prime} " \mathrm{~S} \text { and } \\
48^{\circ} 16^{\prime} 04 " \mathrm{~W}\end{array}$ \\
\hline Temperature $\left({ }^{\circ} \mathrm{C}\right)$ & 17.3 & 20.2 & 20.7 & 19.2 \\
\hline Electrical conductivity $\left(\mu \mathrm{S} . \mathrm{cm}^{-1}\right)$ & 15 & 15 & 58 & 27 \\
\hline Dissolved oxygen $\left(\mathrm{mg} . \mathrm{L}^{-1}\right)$ & 7.6 & 6.6 & 6.8 & 7.1 \\
\hline Oxygen saturation (\%) & 79 & 72.6 & 70.3 & 76.5 \\
\hline Hydrogen ion potential $(\mathrm{pH})$ & 7.1 & 6.9 & 6.9 & 6.8 \\
\hline Dissolved solids (g.L $\left.\mathrm{L}^{-1}\right)$ & 0.01 & 0.01 & 0.04 & 0.02 \\
\hline Canopy cover $(\%)$ & 90 & 70 & 50 & 50 \\
\hline Maximum depth $(\mathrm{cm})$ & 11 & 10 & 2.5 & 2 \\
\hline Maximum channel breadth $(\mathrm{cm})$ & 110 & 80 & 80 & 30 \\
\hline Current speed $(\mathrm{m} / \mathrm{s})$ & 0.25 & 0.14 & 0.16 & $*$ \\
\hline
\end{tabular}

*This speed could not be calculated as the water is too shallow. 
total number of specimens was 4,756, distributed in 73 taxa in 33 families, 818 being caught in the Mina da Casinha stream, where Parametriocnemus and Caladomyia mf1 were most abundant, and 3,938 in the das Furnas stream, where Caladomyia $\mathrm{mf1,Helicopsyche} \mathrm{and} \mathrm{Paratendipes}$ were most common. The estimated richness corroborated these results (see Table 2).

The percentages of Chironomidae and EPT larvae (Ephemeroptera, Plecoptera and Trichoptera) and the ratio of these numbers are shown in Table 3. It may be noted that the Canchim stream showed the highest \% EPT and the highest EPT:Chironomid ratio.

The Shannon diversity, taxon-richness estimated by rarefaction curve (see Figure 2), Margalef's richness and Pielou's evenness (see Table 3) all reflected this general trend in fauna composition, namely greater diversity in the Canchim Farm streams and greater abundance in the Lake Park streams.

The values displayed in Table 3 for Simpson's dominance show generally low dominance in all streams. The highest level of dominance was recorded in the das Furnas stream, due to the large number of specimens of the genera Caladomyia $\mathrm{mf} 1$ and Paratendipes collected in that stream.

The cluster analysis of the streams, based on the abundance of organisms in each, indicated a larger distance (dissimilarity) between Canchim stream and the rest, the other three forming a cluster (see Figure 3), although the greater similarity between the Mina da Casinha and das Furnas streams led to their forming a sub-cluster of two.

Table 2. Taxonomic composition of macroinvertebrates in the dry season (August 2006) in the Canchim (SCan), Sistema (SSis), Mina da Casinha (SMina) and das Furnas (SFur) streams. mf: morphotype; below 1\% ○, from 1 to $3 \% \circ \circ$, from 3 to $5 \%$ ०००, from 5 to $10 \% \bullet$, from 10 to $15 \% \bullet \bullet$, from 15 to $20 \%$

\begin{tabular}{|c|c|c|c|c|}
\hline Taxonomic groups & Scan & SSis & SMina & SFur \\
\hline \multicolumn{5}{|l|}{ Ephemeroptera } \\
\hline Baetidae & $\circ$ & & & $\circ$ \\
\hline Americabaetis & ○ & ○ & & \\
\hline Paracloeodes & $\circ$ & & & $\circ$ \\
\hline Traverhyphes & & & $\circ$ & \\
\hline Leptohyphodes & ০০ & & & \\
\hline Leptophlebiidae & ○ & & & \\
\hline Askola & $\circ$ & & & \\
\hline Farrodes & ○ & & & ○ \\
\hline \multicolumn{5}{|l|}{ Plecoptera } \\
\hline Tupiperla & ० & & & \\
\hline Anacroneuria & ○ & & & ○ \\
\hline Kempnyia & ○ & & & \\
\hline \multicolumn{5}{|l|}{ Trichoptera } \\
\hline \multicolumn{5}{|l|}{ Calamoceratidae } \\
\hline Phylloicus & ○ & & ० & ০০ \\
\hline \multicolumn{5}{|l|}{ Helicopsychidae } \\
\hline Helicopsyche & ০০ & ○ & ० & $\bullet \bullet$ \\
\hline \multicolumn{5}{|l|}{ Hydropsychidae } \\
\hline Blepharopus & $\circ$ & ० & & $\circ$ \\
\hline Smicridea & ○ & ० & ○ & ০০ \\
\hline \multicolumn{5}{|l|}{ Hydroptilidae } \\
\hline Neotrichia & ○ & & & \\
\hline \multicolumn{5}{|l|}{ Leptoceridae } \\
\hline Nectopsyche & $\circ$ & & & \\
\hline Notalina & ० & & & ○ \\
\hline
\end{tabular}


Table 2. Continued ...

\begin{tabular}{|c|c|c|c|c|}
\hline Taxonomic groups & Scan & SSis & SMina & SFur \\
\hline Oecetis & o & & & \\
\hline Triplectides & ○ & & & \\
\hline \multicolumn{5}{|l|}{ Odontoceridae } \\
\hline Marilia & ० & ० & & \\
\hline \multicolumn{5}{|l|}{ Philopotamidae } \\
\hline Chimarra & & & ○ & ० \\
\hline \multicolumn{5}{|l|}{ Polycentropodidae } \\
\hline Cemotina & ० & & & \\
\hline
\end{tabular}

Chironomidae

Orthocladiinae

Corynoneura $m f 1$

Corynoneura $m f 2$

Lopescladius

Nanocladius

Onconeura

Parametriocnemus

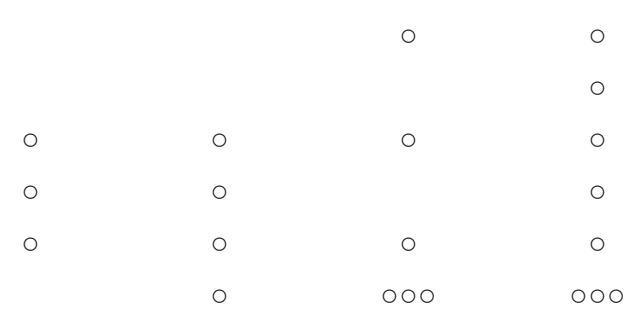

Tanypodinae

Ablabesmyia (Karelia)

Clinotanypus

○

Coelotanypus

Djalmabatista mf1

Djalmabatista mf2

Fittkauimyia

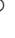

$\bigcirc$

○

$\bigcirc$

O

000

Labrumdinia

Larsia

Macropelopini

Nilotanypus

Pentaneura mf1

Pentaneura mf2

Pentaneurini

Procladius

Zavrelimyia

Chironominae

Beardius

Caladomyia mf1

Caladomyia $\mathrm{mf} 2$

Chironomus mf1

Chironomus mf2

Chironomus mf3 
Table 2. Continued ...

\begin{tabular}{|c|c|c|c|c|}
\hline Taxonomic groups & Scan & SSis & SMina & SFur \\
\hline Fissimentum & ○ & & & \\
\hline Goeldichironomus gr. Pictus & & ○ & & \\
\hline Harnischia mf1 & ○ & ○ & & ○ \\
\hline Lauterborniella $\mathrm{mf} 1$ & ○ & & & \\
\hline Lauterborniella $\mathrm{mf} 2$ & ○ & ○ & ○ & ○ \\
\hline Paratendipes & $\circ$ & ○ & ○ & $\bullet \bullet$ \\
\hline Phaenopsectra & ○ & & & \\
\hline Polypedilum mf1 & ○ & $\circ$ & ○ & $\circ$ \\
\hline Polypedilum gr. fallax & ○ & & & \\
\hline Pseudochironomus & ○ & & & ० \\
\hline Rheotanytarsus mf1 & o & & & o \\
\hline Rheotanytarsus mf2 & ○ & & ○ & ০০ \\
\hline Stempelina & O & & & \\
\hline Stenochironomus & ○ & ○ & o & ० \\
\hline Tanytarsus mf1 & ○ & ० & ० & ○ \\
\hline Tanytarsus $\mathrm{mf} 2$ & & ○ & & \\
\hline Tanytarsus rabdomantis & ○ & ○ & & ० \\
\hline Zavreliella mf1 & ○ & & & \\
\hline Zavreliella $\mathrm{mf} 2$ & ○ & & & \\
\hline \multicolumn{5}{|l|}{ Diptera } \\
\hline Ceratopogonidae mf1 & ○ & ○ & ○ & ০০ \\
\hline Ceratopogonidae mf3 & & & ○ & \\
\hline Culicidae & & & o & ० \\
\hline Dixidae & & ○ & & \\
\hline Empididae & ○ & & o & ○ \\
\hline Ephydridae & & & & ○ \\
\hline Psychodidae & & & & $\circ$ \\
\hline Simuliidae & ○ & ○ & ○ & ○ \\
\hline Stratiomydae & & & & ○ \\
\hline Tabanidae & ० & & & ○ \\
\hline Tipulidae & ○ & ○ & ० & O \\
\hline \multicolumn{5}{|l|}{ Odonata } \\
\hline Calopterygidae & ○ & ○ & & \\
\hline Argia & ○ & ○ & o & o \\
\hline Neocordulia & $\circ$ & & & \\
\hline Progomphus & & & ○ & ० \\
\hline Phyllogomphoides & ○ & & & \\
\hline Gomphoides & & ○ & & \\
\hline Dasythemis & ○ & & o & \\
\hline Brechmorhoga & $\circ$ & ○ & ○ & ० \\
\hline Idiataphe & & ○ & & O \\
\hline
\end{tabular}


Table 2. Continued ...

\begin{tabular}{|c|c|c|c|c|}
\hline Taxonomic groups & Scan & SSis & SMina & SFur \\
\hline Gynothemis & o & & o & o \\
\hline Macrothemis & & & & ० \\
\hline Micrathyria & & & ० & \\
\hline Elga & & & ० & \\
\hline Planiplax & & & ○ & ० \\
\hline Oxistigma & ० & & & \\
\hline
\end{tabular}

Megaloptera

Chloronia

Hemiptera

Gerridae

Naucoridae

Pleidae

Veliidae

Hebridae

\section{Coleoptera}

Curculionidae

Dryopidae

Dryops

Larva A

Cylloepus

Heterelmis

Hexacylloepus

Microcylloepus

Phanocerus

Hydraena

Tropisternus

Stenus

hrysomelidae sp1

Lepdoptera

Pyralidae

Oligochaeta

Brinkhurstia

Dero

Nais

Pristina

Slavina 
Table 3. Metrics calculated for the Canchim, Sistema, Mina da Casinha (Mina) and das Furnas streams in the dry period. $\mathrm{S}=$ observed taxon richness; $\mathrm{S}^{*}=$ taxon richness estimated from the rarefaction curve for 350 specimens; $\mathrm{N}=$ abundance; $\mathrm{d}=$ Margalef richness; E = Pielou's evenness; H' = Shannon diversity; D = Simpson dominance; 1-D = Simpson diversity.

\begin{tabular}{lccrrrrrrrrr}
\hline & S & \multicolumn{1}{c}{ S* } & \multicolumn{1}{c}{ N } & \multicolumn{1}{c}{ d } & E & H' & 1-D & D & EPT/Chiro & \%Chiro & \%EPT \\
\hline Canchim & 92 & 60.5 & 1217 & 12.81 & 0.77 & 3.48 & 0.95 & 0.05 & 2.30 & 21.36 & 48.97 \\
Sistema & 51 & 50.6 & 358 & 8.50 & 0.77 & 3.02 & 0.92 & 0.08 & 0.34 & 35.19 & 11.73 \\
Mina & 48 & 37.4 & 817 & 7.01 & 0.70 & 2.71 & 0.88 & 0.12 & 0.14 & 58.50 & 8.20 \\
Furnas & 62 & 31.6 & 3920 & 7.37 & 0.59 & 2.44 & 0.85 & 0.15 & 0.39 & 64.92 & 25.25 \\
\hline
\end{tabular}

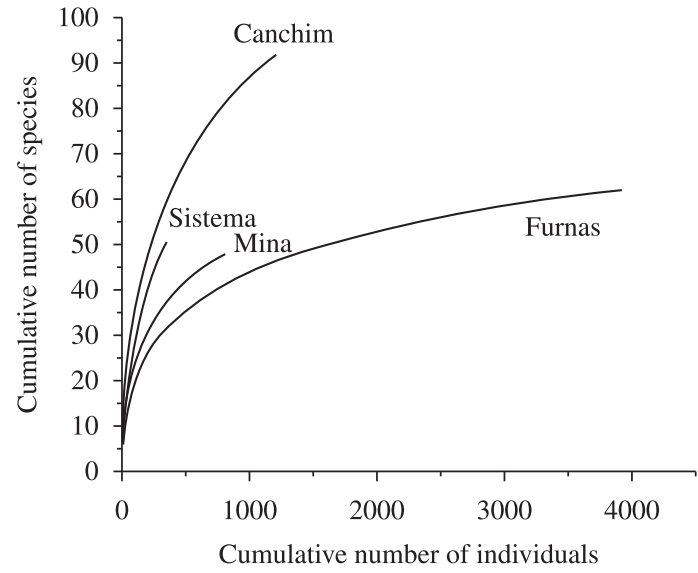

Figure 2. Rarefaction curve for total macroinvertebrate fauna collected in the dry season from the Canchim, Sistema, Mina da Casinha (Mina) and das Furnas (Furnas) streams.

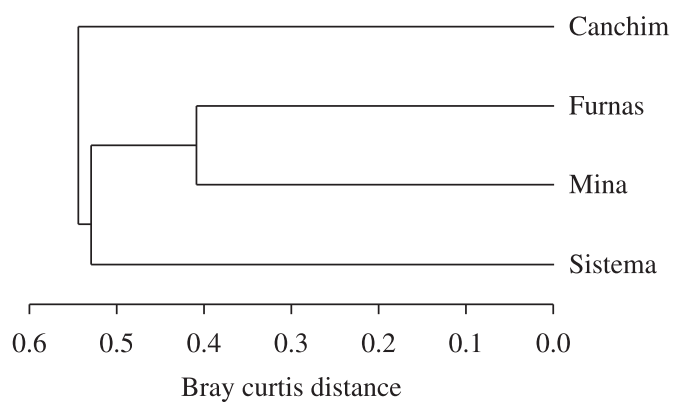

Figure 3. Cluster analysis based on the Bray-Curtis dissimilarity index, with $\log _{10}(x+1)$ - transformed abundance data.

\section{Discussion}

Freshwater ecosystems reflect the character of the surrounding land: geomorphology, physiognomy, regional climate, natural gradients arising from seasonal changes (Wetzel and Linkes, 1991) and disturbances due to human activity (Rosenberg and Resh, 1993).

Among the observable environmental variables that influence the condition of streams, the state of the riparian vegetation stands out as the most important for the maintenance of natural stream-processes (Gregory et al., 1991). This is because the riverside plants contribute most of the organic matter and nutrients received by streams (Bunn et al., 1999), especially low-order streams in forested areas.

Besides riparian forest, several environmental factors influence the presence and distribution of macroinvertebrates, the most important being the temperature and dissolved oxygen content of the water (Ward, 1992), which are subject to local variation.

Temperature is a key variable in the regulation of other variables and of the biota in rivulets (Ward, 1992). When the riverside forest is totally or partially cleared, the temperature of the water rises as a result of the lack of shade. This may explain, in the present study, the raised temperatures of the Sistema stream, located at the edge of the forest, and of the Mina da Casinha and das Furnas streams in Lake Park, whose forest is less dense, as is evident in the smaller amount of canopy cover, compared to the Canchim stream.

The dissolved oxygen concentration is one of the most important limnological variables, both to characterise aquatic habitats and to maintain aquatic life. Whitton (1975) pointed out that waterborne organisms need different amounts of oxygen, which could affect their distribution. However, in the streams under study, the levels of dissolved oxygen were high and thus not a limiting factor for the fauna.

From the results of this study, the Canchim stream can be adopted as a reference site, based on the high values of the Shannon diversity index and taxon richness (observed and estimated), as well as on the diversity of EPT genera. Roque (2000) studied macroinvertebrates in streams in the Jaraguá State Park, Suriano and Fonseca-Gessner (2004) analysed chironomids in streams in the Campos do Jordão State Park and Cetra and Petrere (2007) studied the association of fish with the riparian vegetation, corroborating the present findings, the studies reported the highest taxon richness where the riparian forest was dense and effective at various levels, such as depth of coverage and canopy cover.

All orders of insects, including the immature stages of EPT, are of great importance in the study of the communities in low to medium order lotic habitats (Baptista et al., 2001). In these systems, EPT insects normally exhibit high species richness and are essential links in the transfer of energy through the food chain (Bispo, 2002). In addition, they are seen as good environmental indicators, being especially sensitive to disturbances of the aquatic ecosystem that arise from deforestation (Bispo et al., 2001; Bispo and Oliveira, 1998). Thus, the predominance and diversity of the EPT 
genera in the Canchim stream confirm the above conclusion that this stream is was also common in significantly better conserved than the other three. The EPT population the Furnas stream, albeit at a lower diversity, indicating that despite running through an area of reforestation, in which the plant cover is still light, this stream has features that sustain the more sensitive macroinvertebrates.

Among the taxa predominating in all four streams, the Chironomidae are pre-eminent. According to Marques et al. (1999), this family can be considered common and tolerant to a wide array of environmental conditions. The number of chironomid species inhabiting any freshwater body is normally far superior to that of any other taxonomic group (Int Panis, 1995).

The high EPT:Chironomidae ratio in the Canchim and Sistema streams, both of which are located in a conservation area, indicates their superior environmental quality, reflecting the low level of human interference, in contrast to the lower ratios in the Lake Park streams, whose riparian forest is in the process of recovery. In the same region, similar results have been reported by Guereschi and Fonseca-Gessner (2000), for streams in the Jataí Ecological Station (Luiz Antônio district, SP), and by Kleine and Trivinho-Strixino (2005), in the Fazzari stream in São Carlos (SP): these authors observed lower EPT:Chironomidae ratios in stretches lacking vegetation on the banks and where organic effluents may have been present.

Results for the Mina da Casinha and das Furnas streams indicated that they were closest in the cluster analysis, due to their high abundances of macroinvertebrates, in spite of the sparse riparian forest. Wallace et al. (1988), who compared brooks with and without riverside vegetation in North Carolina (USA), also observed that invertebrates were more abundant in those without vegetation. Hawkins et al. (1983), Angermeier and Karr (1983) e Wallace et al. (1988) have proposed that the higher numbers of macroinvertebrates in streams lacking riparian vegetation may be attributed to the increased availability of food due to high levels of primary production by algae.

Lower diversity of macroinvertebrate taxa has been reported in streams subjected to partial removal of riparian vegetation from various regions, both in North America (Clenaghan et al., 1998; Harding et al., 1998) and the tropics (Giller and Twomey, 1993). Corbi and Trivinho-Strixino (2006), investigating tributary streams of the Jacaré-Guaçu River (SP) in forested, grazing and sugarcane-planted areas, also reported lower diversity in streams affected by degradation of riparian forest.

In conclusion, the Canchim stream may be taken as a reference site, as it supports very diverse fauna, including rare and sensitive taxa, and is protected by a dense and conserved riparian forest. The Sistema stream, although in the same forest, is located at its edge and thus is affected by the neighbouring cattle pasture, making it similar, in terms of quality, to the Mina da Casinha and das Furnas streams, whose riverside forest is undergoing managed recovery.

\section{References}

ALLAN, JD., 2004. Landscapes and Riverscapes: The Influence of Land Use on Stream Ecosystems. Annual Review of Ecology Evolution System, vol. 35, p. 257-284.

ANGERMEIER, PL. and KARR, JR., 1983. Fish communities along environmental gradients in a system of tropical streams. Environmental Biology of Fish, vol. 9, no. 2, p. 117-135.

ANGRISANO, EB. and KOROB, PG., 2001. Trichoptera. In FERNÁNDEZ, HR. and DOMÍNGUEZ, E. (Eds.). Guía para determinación de los artrópodos bentónicos sudamericanos. San Miguel de Tucumán: Universidad Nacional de Tucumán. Faculdad de Ciencias Naturales, Instituto M. Lillo, p. 5-92.

BAPTISTA, DF., BUSS, DF., DORVILLÉ, LFM. and NESSIMIAN, JL., 2001. Diversity and habitat preference of aquatic insects along the longitudinal gradient of the Macaé river basin, Rio de Janeiro, Brazil. Brazilian Journal of Biology, vol. 61, no. 2.

BERTRAND, HPI., 1972. Larves et nymphes des coléoptères aquatiques du globe. Parise: F. Paillart/Abbevill.

BISPO, PC. and OLIVEIRA, LG., 1998. Distribuição espacial de insetos aquáticos (Ephemeroptera, Plecoptera e Trichoptera) em córregos de cerrado do Parque Ecológico de Goiânia, Estado de Goiás. In: NESSIMIAN, JL. and CARVALHO, AL. (Eds.). Ecologia de Insetos Aquáticos. Rio de Janeiro: UFRJ/Instituto de Biologia, p. 175-189. Série Oecologia Brasiliensis.

BISPO, PC., 2002. Estudo de comunidades de Ephemeroptera, Plecoptera e Trichoptera (EPT) em riachos do Parque Estadual Intervales, Serra de Paranapiacaba, Sul do Estado de São Paulo. São Paulo: Instituto de Biociências, Universidade de São Paulo, 120 p. [Tese Doutorado].

BISPO, PC., OLIVEIRA, LG., CRISCI, VL. and SILVA, MM., 2001. Pluviosidade como fator de alteração de entomofauna bentônica (Ephemeroptera, Plecoptera e Trichoptera) em córregos do Planalto Central do Brasil. Acta Limnologica Brasiliensia, vol. 13 , no. 2, p. 1-9.

BRINKHURST, RO. and MARCHESE, M., 1989. Guia para la identificacion de Oligochaetos acuaticos de Sud y Centroamérica. Argentina: Asociación Ciencias Naturales del Litoral., 207 p. Coleção Climax, 5.

BUNN, SE., DAVIDES, PM. and MOSISCH, TD., 1999. Ecosystem measures of river health and their response to riparian and catchment degradation. Freshwater Biology, vol. 41, no. 2, p. 333-345.

Cetra, M. and Petrere Jr., M., 2007. Associations between fish assemblage and riparian vegetation in the Corumbataí River Basin (SP). Brazilian Journal of Biology, vol. 67, no. 2.

CLARKE, A., MAC NALLY, R., BOND, N. and LAKE, PS., 2008. Macroinvertebrate diversity in headwater streams: a review. Freshwater Biology, vol. 53, no. 9, p. 1707-1721.

CLENAGHAN, C., GILLER, PS., O’HALLORAN, J. and HERNAN, R., 1998 Stream macroinvertebrate communities in a conifer-afforested catchment in Ireland: relationships to physico-chemical and biotic factors. Freshwater Biology, vol. 40, no. 1 , p. 175-193.

CORBI, JJ. and TRIVINHO-STRIXINO, S., 2006. Influence of taxonomic resolution of stream macroinvertebrate communities on the evaluation of different land uses. Acta Limnologica Brasiliensia, vol. 18, no. 4, p. 469-475. 
COSTA, C., VANIN, S. and CASARI-CHEN, A., 1988. Larvas de Coleoptera do Brasil. São Paulo: USP/Museu de Zoologia, Universidade de São Paulo, 447 p.

COSTA, JM., SOUZA, LOI. and OLDRINI, BB., 2004. Chave para identificação das famílias e gêneros das larvas conhecidas de Odonata do Brasil: comentários e registros bibliográficos (Insecta, Odonata). Rio de Janeiro: Museu Nacional, no. 99, p. 3-42.

DOMÍNGUEZ, E., HUBBARD, MD., PESCADOR, ML. and MOLINERI, C., 2001. Ephemeroptera. In FERNANDEZ, HR. and DOMÍNGUEZ, E. (Ed.). Guía para la Determinación de los Artrópodos Bentónicos Sudamericanos. Tucumán: Editorial Universitaria de Tucumán, p. 17-53.

DOMÍNGUEZ, E., MOLINERI, C., PESCADOR, ML., HUBBARD, MD. and NIETO, C., 2006. Aquatic Biodiversity in Latin America: Ephemeroptera of South America. Sofia, Moscow: Ed. Pensoft, $646 \mathrm{p}$.

DUDGEON, D., 1988. The influence of riparian vegetation on macroinvertebrates community structure in four Hong Kong streams. Journal of Zoology, vol. 216, p. 609-627.

EPLER, JH., 1996. Dentification manual for the water beetles of Florida. Tallahassee, Florida: State of Florida Department of Environmental Protection. Division of Water Facilities.

FERNÁNDEZ, HR. and DOMÍNGUES, E., 2001. Guia para la determinación de los artrópodos bentônicos sudamericanos. Tucumán: Universidad Nacional de Tucumán, 282 p.

FROEHLICH, CG., 1998. Chave para gêneros de Plecoptera do sudeste do Brasil.

GILLER, PS. and TWOMEY, H., 1993. Benthic macroinvertebrate community organization in two contrasting rivers - between-site differences and seasonal patterns. Biology Environment, vol. 93B, p. $115-126$.

GREGORY, SV., SWANSON, FJ., McKEE, WA. and CUMMINS, KW., 1991. An ecosystem perpective of riparian zones: focus on links between land and water. BioScience, vol. 41, p. 540-551.

GUERESCHI, RM. and FONSECA-GESSNER, AA., 2000. Monitoramento da Estação Ecológica de Jataí - Luiz Antônio (SP) utilizando os macroinvertebrados bentônicos como bioindicadores. In SANTOS, JE. and PIRES, SR. (Eds.). Estação Ecológica de Jataí: estudos integrados em ecossistemas. São Carlos: Rima, vol. 4, p. 75-98.

HARDING, JS., BENFIELD, EF., BOLSTAD, PV., HELFMAN, GS. and JONES, EBD., 1998. Stream biodiversity: the ghost of land use past. Proceedings of the National Academy of Sciences, vol. 95, p. 14843-14847.

HAWKINS, CP., MURPHY, ML., ANDERSON, NH. and WILBACH, MA., 1983. Density of fish and salamanders in relation to riparian canopy and physical habitat in streams of the northwestern United States. Canadian Journal of Fisheries and Aquatic Sciences, vol. 40, no. 8, p. 1173-1185.

HYNES, HBN., 1970. The ecology of running waters. Toronto: Toronto Press, 555 p.

INT PANIS, L., 1995. The spatial distribution of benthic invertebrates in standing waters. Antwerpen: Universitaire Instelling Antwerpen,. 181 p. [Tese de Doutorado]. In CALLISTO, M. and ESTEVES, F., 1998. Biomonitoramento da macrofauna bentônica de Chironomidae (Diptera, Insecta) em dois igarapés amazônicos sob influência das atividades de uma mineração de bauxita. vol. 5, p. 299-309. Série Oecologia Brasiliensis.
KIKUCHI, RM. and UIEDA, VS., 1998. Composição da comunidade de Invertebrados de um ambiente lótico tropical e sua variação espacial e temporal. In: NESSIMIAN, JL. and CARVALHO, E. (Eds.). Ecologia de insetos aquáticos, vol. 5, p. 157-173. Série Oecologia Brasiliensis.

KLEINE, P. and TRIVINHO-STRIXINO, S., 2005. Chironomidae and other aquatic macroinvertebrates of a first order stream: community response after habitat fragmentation. Acta Limnologica Brasiliensia, vol. 17, no. 1, p. 81-90.

LEECH, HB. and CHANDLER, HP., 1956. Coleoptera. In: USINGER, RL. (Ed.). Aquatic insects of California: with keys to North American genera and California species. Berkeley, Los Angeles: University of California Press, p. 293-376.

LIND, OT., 1979. Handbook of common methods in Limnology. St Louis: The C.V. Mosby Company, 199 p.

MANZO, V., 2005. Key to the South America genera of Elmidae (Insecta: Coleoptera) with distributional data. Studies on Neotropical Fauna and Environment, vol. 40, no. 3, p. 201-208.

MARQUES, MMGSM., BARBOSA, FAR. and CALLISTO, M., 1999. Distribution and abundance of Chironomidae (Diptera, Insecta) in an impacted watershed in south-east Brazil. Revista Brasileira de Biologia $=$ Brazilian Journal of Biology, vol. 59, no. 4 .

OLIFIERS, MH., DORVILLÉ, LFM., NESSIMIAN, JL. and HAMADA, N., 2004. A key to Brazilian genera of Plecoptera (Insecta) base don nymphs. Zootaxa, vol. 651, p. 1-15.

PES, AMO., HAMADA, N. and NESSIMIAN, JL., 2005. Chaves de identificação de larvas para famílias e gêneros de Trichoptera (Insecta) da Amazônia Central, Brasil. Revista Brasileira de Entomologia, v. 49, n. 2, p. 181-204.

RODRIGUES, RR. and LEITÃO-FILHO, HF. (Eds.), 2001. Matas ciliares: conservação e recuperação. São Paulo: Edusp, p. 271-287.

ROQUE, FO., 2000. Distribuição espacial dos macroinvertebrados bentônicos nos córregos do Parque Estadual do Jaraguá (SP): considerações para a conservação ambiental. São Carlos: Departamento de Hidrobiologia, Universidade Federal de São Carlos, 76 p. [Tese de Doutorado].

ROSENBERG, DM. and RESH, VH., 1993. Freshwater Biomonitoring and Benthic Macroinvertebrates. New York: Chapmann \& Hall, 488 p.

SALLES, FF., DA-SILVA, ER., SERRÃO, JE. and FRANCISCHETTI, CN., 2004. Baetidae (Ephemeroptera) na Região Sudeste do Brasil: novos registros e chave para os gêneros no estágio ninfal. Neotropical Entomology, vol. 33, no. 5, p. 569-576.

SURIANO, MT. and FONSECA-GESSNER, AA., 2004. Chironomidae (Diptera) larvae in streams of Parque Estadual de Campos do Jordão, São Paulo state, Brazil. Acta Limnologica Brasiliensia, vol. 16, no. 2, p. 129-136.

TRIVINHO-STRIXINO, S. and STRIXINO, G., 1995. Larvas de Chironomidae (Diptera) do Estado de São Paulo: guia de identificação de diagnose dos gêneros. São Carlos: UFSCar / PPG-ERN, 229 p.

VANNOTE, RL., MINSHALL, GW., CUMMINS, KW., SEDELL, JR. and CUSHING, CE., 1980. The river continuum concept. Canadian Journal of Fisheries and Aquatic Sciences, v. 37, p. 130-137. 
WALLACE, JB., GURTZ, ME. and SMITH-CUFFNEY, F., 1988. Long-term comparisons of insect abundances in disturbed and undisturbed Appalachian headwater streams. Verhandlungen der Internationalen Vereinigung fur theoretische und angewandte. Limnologie, vol. 23, p. 1224-1231.

WARD, JV., 1992. Aquatic Insect Ecology I: biology and habitat. John Wiley \& Sons Inc., $450 \mathrm{p}$.

WETZEL, RG. and LIKENS, GE., 1991. Limnological Analyses. New York: Springer-Verlag, 391 p.
WHITE, DS. and BRIGHAM., 1996. Coleoptera. In MERRITT, RW. and CUMMINS, KW. (Eds.). An introduction to the Aquatic Insects of North America. Dubaque, Iowa: Kendall/Hunt Publishing Company, p. 399-473.

WHITTON, BA., 1975. River Ecology. Oxford: Blackwell Scientific Publications, $725 \mathrm{p}$.

WIGGINS, GB., 1996. Larvae of the North American Caddisfly Genera (Trichoptera). 2. ed. Toronto: University of Toronto Press, $401 \mathrm{p}$. 